\title{
Large- and small-scale movement and distribution of acoustically tagged lake sturgeon (Acipenser fulvescens) in eastern Lake Erie
}

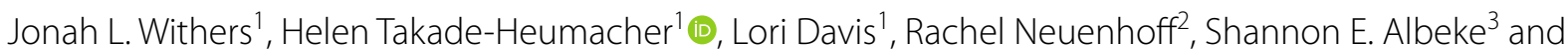
John A. Sweka ${ }^{1 *}$

\begin{abstract}
Background: Defining the spatial distribution, home range, and movement patterns of lake sturgeon (Acipenser fulvescens) is important to managers and decision-makers given the large migration potential and potamodromous behavior exhibited by the species. A remnant population of lake sturgeon remains in the far eastern basin of Lake Erie and although recent efforts have estimated the population size, described the age distribution, and identified a primary spawning site no study to date has examined the spatial distribution or movements of individuals within this population. Between 2014 and 2018, we acoustically tagged 59 adult lake sturgeon, captured in the Buffalo Harbor area, and monitored their large-scale movements throughout Lake Erie with the Great Lakes Acoustic Telemetry System and small-scale movements with a Vemco Positioning System in the Buffalo Harbor area. After dividing Lake Erie into seven sections, we ran a multi-state mark-recapture model to examine the movement rates into and out of the eastern most section of the lake. Within a heavily utilized lake section, in the Buffalo Harbor area, we identified home ranges with our Vemco Positioning System for each season and year using averaged Brownian bridge movement models.
\end{abstract}

Results: Although some sturgeon demonstrated large-scale movements, traversing the entirety of Lake Erie, the majority of individuals spent their time in the eastern basin of the lake. Home ranges appeared to vary among seasons, but were consistent across years with lake sturgeon selecting the northeastern, rocky, and shallow area of our array during pre-spawning and spawning seasons and leaving our array, or selecting a trough running along the northwestern portion of our array comprising sand and bedrock, in the summer and fall seasons.

Conclusions: Documenting these large-scale movements aligns with previous findings that lake sturgeon on either end of the lake are genetically similar and demonstrates lake sturgeon in the eastern basin exhibit strong philopatry. Our small-scale movement models provide managers with spatial reference points, in the form of utilization distributions, indicating heavily used areas by lake sturgeon within seasons. Future studies should examine what parameters are driving site selection in these areas.

Keywords: Lake sturgeon, Telemetry, Acipenser fulvescens, Movement, Lake Erie, Distribution

${ }^{*}$ Correspondence: John_Sweka@fws.gov

${ }^{1}$ Northeast Fishery Center, U.S. Fish \& Wild life Service, P.O. Box 75, Lamar, PA 16848, USA

Full list of author information is available at the end of the article permits use, sharing, adaptation, distribution and reproduction in any medium or format, as long as you give appropriate credit to the original author(s) and the source, provide a link to the Creative Commons licence, and indicate if changes were made. The images or other third party material in this article are included in the article's Creative Commons licence, unless indicated otherwise in a credit line to the material. If material is not included in the article's Creative Commons licence and your intended use is not permitted by statutory regulation or exceeds the permitted use, you will need to obtain permission directly from the copyright holder. To view a copy of this licence, visit http://creativecommons.org/licenses/by/4.0/. The Creative Commons Public Domain Dedication waiver (http://creativeco mmons.org/publicdomain/zero/1.0/) applies to the data made available in this article, unless otherwise stated in a credit line to the data. 


\section{Background}

Identifying movements and spatial use of individual animals provides managers with information about a species' population distributions, resources used, and critical habitat as well as insights into the animal's biology and behavior [1-3]. Though initial efforts to monitor aquatic organisms' movements relied on mark-recapture and visual observation efforts, technological advances have provided researchers the ability to monitor movements of aquatic animals at higher frequencies and, in some cases, with high accuracy. The recent development of global telemetry networks has fostered geographically large collaborations among researchers that have broadened capabilities to track aquatic animals, particularly migratory species [4].

Acoustic (or ultrasonic) telemetry has been used to track movements of aquatic animals since the 1950s (as described in [5]) and involves the use of transmitters and receivers wherein the transmitters emit a unique code in the form of ultrasonic pulses that can be detected, decoded, and logged by the receivers. Acoustic telemetry has traditionally been employed using either active tracking or passive monitoring. The logistical limitations of manually tracking migratory fish generally preclude researchers from studying multiple tagged individuals over broad spatial scales with high temporal resolution. Alternatively, passive acoustic telemetry allows for monitoring of multiple tagged individuals and can cover vast spatial areas depending on the acoustic receiver array design. Additionally, passive acoustic telemetry can be used to triangulate acoustic transmissions provided a transmission is detected on three unique acoustic receivers [6]. Although passive acoustic telemetry provides a means to monitor broad spatial areas and circumvents the labor intensive demands of active tracking, the costs associated with developing large-scale passive acoustic arrays has prevented many studies from examining large-scale animal movements. However, the development of acoustic telemetry networks (e.g., Integrated Marine observation system (IMOS), Great Lakes Acoustic Telemetry Observation System (GLATOS), Atlantic Cooperative Telemetry (ACT), Ocean Tracking network (OTN), and Australian Ocean Data Network (AODN)) and the infrastructure they provide are diminishing these financial hurdles.

Lake sturgeon (Acipenser fulvescens) is a large, longlived, potadromous fish species distributed throughout the Laurentian Great Lakes. Lake sturgeon underwent precipitous population declines in the mid to late 1800 s due to overexploitation and habitat degradation [7-9]. Lake Erie historically supported the largest lake sturgeon commercial fishery, with reported harvests reaching nearly 5.2 million pounds in 1885; over 3.7 million pounds of which was harvested out of New York State waters [10]. Despite the closure of the commercial fishery in 1984 and listing of the species as threatened or endangered in state, provincial, and federal waters in the late 1900 s and early 2000s [11, 12], lake sturgeon populations within Lake Erie have demonstrated slow recovery rates $[13,14]$. At least a portion of this slow recovery can be attributed to aspects of lake sturgeon life history. Lake sturgeon mature relatively late, starting between 12 to 18 years depending on sex, and do not spawn every year [8]. Given the long time to maturity, lake sturgeon have a life history that makes the species easily susceptible to overexploitation [15].

A small remnant group of lake sturgeon congregates in the far eastern basin of Lake Erie near the headwaters of the Niagara River that we identify as the Buffalo Harbor area [16]. Though initial studies have identified a spawning site [16], described the age structure [17], and estimated abundance [18], no study to date has documented the large- or small-scale movements of this population. It is important to identify large- and small-scale lake sturgeon movement given their longevity, spawning behaviors, life-history related habitat changes, and ability to move large distances. Documenting movement patterns at both scales can identify home ranges, habitat use, spawning periodicity, critical habitat, movement corridors, and provides a baseline for determining possible habitat fragmentation.

Our goals for this study were to identify the largeand small-scale movements of the lake sturgeon population that occupies the far eastern basin of Lake Erie and spawns at the headwaters of the Niagara River. The large-scale movement objectives of our study were to use acoustic telemetry to identify the distribution, movement, and range of the population, as well as to identify if movement patterns emerge among tagged individuals. The small-scale movement objectives were to use acoustic telemetry to identify the fine-scale seasonal movements and home range of this population, e.g., areas of high use or high utilization distribution.

\section{Methods \\ Study area}

Our study area extended from the headwaters of the Niagara River in far eastern Lake Erie to far western Lake Erie up through the Detroit River and Lake St Clair. Lake Erie itself is $388 \mathrm{~km}$ long with a maximum depth of $64 \mathrm{~m}$ and an average depth of $19 \mathrm{~m}$. Lake Erie is the shallowest of the Great Lakes and, despite efforts to reduce nutrient loading, experiences hypoxic conditions during the summer months in the central basin $[19,20]$. The lake comprised three basins - western, central, and eastern-with depth increasing from west to east. Buffalo Harbor is 
located at the headwaters of the upper Niagara River at the far eastern end of the lake and frequently freezes over in the winter. The eastern portion of Lake Erie, which includes Buffalo Harbor and the Niagara River, has a variety of bottom substrates including clay, sand, gravel, and exposed bedrock [21].

\section{Capturing and processing lake sturgeon}

Between 2014 and 2018, we captured sub-adult and adult lake sturgeon from mid-May to mid-June using two types of gillnets. One was a $91.44 \mathrm{~m}$, experimental monofilament net that was $1.83 \mathrm{~m}$ deep, with a $27.22 \mathrm{~kg}$ leadcore line and $1.27 \mathrm{~cm}$ foam-core float line. This net was equipped with mesh sizes of 20.32, 25.40 and $20.48 \mathrm{~cm}$ alternating sequentially in $15.24 \mathrm{~m}$ panels. The other net was the same length and depth, but consisted of mixed mono- and multifilament mesh of sizes 25.40, 30.48, and $35.56 \mathrm{~cm}$. The nets were fished as bottom anchored gillnets. We set nets near the headwaters of the Niagara River by the North Gap breakwall (Fig. 1) and fished during daylight hours for 2-4 $\mathrm{h}$ each deployment.

We held captured sturgeon in a holding tank before measuring and tagging them. We took morphometric measurements from all captured lake sturgeon and assigned sex when evident through the expression of gametes, via ultrasound [22], endoscopy, or observations of the gonads when implanting acoustic transmitters. Each captured lake sturgeon received a unique passive integrated transponder (PIT) under the first dorsal scute and a FLOY T-Bar anchor tag (Floy Tag \& Mfg. Inc., Seattle, Washington, USA) was inserted into the base of the dorsal fin.

A subset of captured lake sturgeon received an acoustic transmitter (Table 1). Prior to surgery, we sterilized all surgical equipment, including the transmitter, in a $10 \%$ betadine solution. We took an initial assessment of condition by measuring opercular movements per minute (OMPM). We then transported the fish to a soft, mesh stretcher where it was anesthetized using a flowthrough system that passed lake water mixed with tricaine methane sulfonate ( MS-222, $150 \mathrm{mg} / \mathrm{L}$ ), and baking soda $(150 \mathrm{mg} / \mathrm{L})$ to buffer the acidic nature of MS-222, continuously over the fish's gills. We made an incision, 38-64 $\mathrm{mm}$ long, between the third and fifth ventral scute anterior to the pelvic fins and offset from the ventral midline after we sanitized the area with $10 \%$ betadine. We inserted a 69-kHz Vemco V16-4H transponder (Vemco; Halifax, Nova Scotia, Canada; length $71 \mathrm{~mm}$ diameter $16 \mathrm{~mm}$; 50-150 s tag delay; 10-year battery life) intraperitoneally via the incision which was closed using three to five monofilament sutures (Ethicon PDS-II size 0 with OS- 6 half-circle reverse cutting needle) and tissue cement (3M, Vetbond). We injected oxytetracycline hydrochloride (OTC) intraperitoneally $(40 \mathrm{~mL} / \mathrm{kg}$ ) for prophylactic and therapeutic purposes as well as to label calcified structures [23]. Following surgery, we moved the lake sturgeon from the stretcher to a holding tank wherein OMPM were measured. Once OMPM measurements were similar to pre-surgery measurements, the fish was deemed ready for release. We transported the lake sturgeon to their point of capture where tags and transmitters were checked, to ensure they were functioning properly, prior to releasing the fish.

\section{Data collection: passive acoustic telemetry arrays}

We monitored acoustically tagged lake sturgeon on two acoustic telemetry systems: (1) the Great Lakes Acoustic Telemetry Observation System (GLATOS; http://glatos. glos.us); and (2) a Vemco Positioning System (VPS) we deployed in the Buffalo Harbor area near the capture/ release site. Both systems comprised stationary, omnidirectional VR2W, VR2Tx, and VR2AR receivers (Vemco; Halifax, Nova Scotia, Canada). Receivers were generally fixed to moorings; mostly in either a cylindrical polyvinyl chloride (PVC) plastic housing embedded in a concrete mooring, hose-clamped to an aluminum rod with buoys that was then shackled to the concrete mooring, or hose-clamped to an acoustic release that was tethered to a concrete mooring; and deployed along the bottom of the lake.

\section{GLATOS: Large-scale movement monitoring}

The GLATOS, established in 2010, is a bi-national network of researchers collaboratively using acoustic telemetry to answer questions about fish behavior and movement to facilitate management decisions in the Great Lakes basin. Participants deploy and retrieve Vemco receivers throughout the Great Lakes basin and share their receivers' detection data with a centralized data repository. Participants are then able to query all data collected and stored within the centralized data repository pertaining to transmitters they deployed.

Receiver deployment locations changed over time with the commencement and completion of individual acoustic telemetry projects within the GLATOS network (Fig. 2). Additionally, many receivers throughout the lake were deployed on a seasonal basis between 2016 and 2018. Given the seasonal nature of receiver deployments, analyses were restricted to the last day of receiver deployment and the first day of receiver retrieval in Buffalo Harbor within each year (Table 2). This resulted in analysis time frames of unequal length.

\section{Fine-scale movement monitoring}

Between 2016 and 2018, we deployed VR2W and VR2Tx Vemco receivers in a $6 \mathrm{~km}^{2}$ grid-style array in Buffalo 


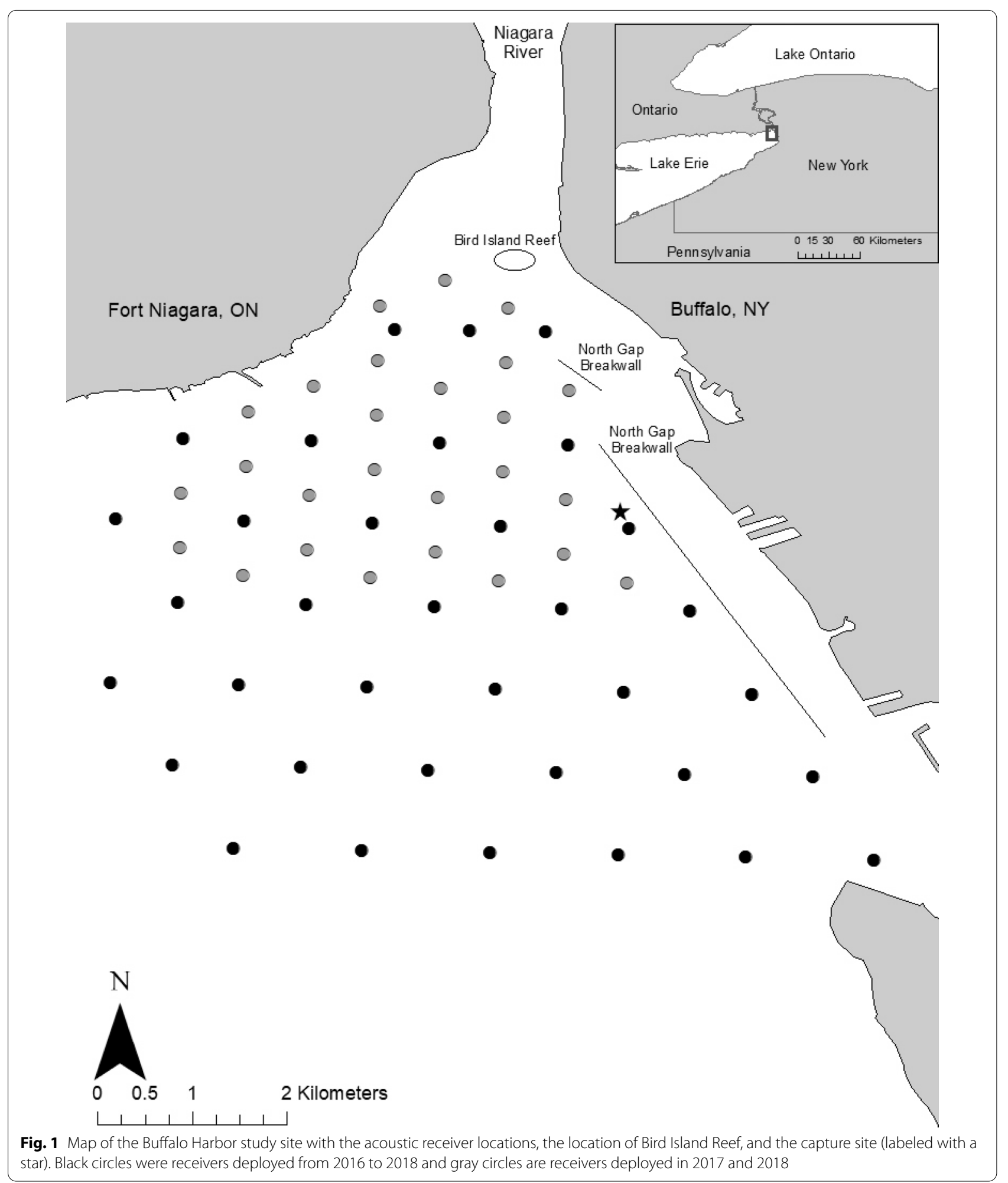

Harbor. During 2016 the grid consisted of 35 receivers spaced $1 \mathrm{~km}$ apart. During 2017 and 2018, we incorporated an additional 26 receivers into the grid to increase detection probability within the same study area used during 2016 (Fig. 1). By increasing receiver density in 2017 and 2018, the array gained triangulation position 
Table 1 Sampling dates, number of net sets, number of lake sturgeon captured, and catch per unit effort (number per net hour) of spring lake sturgeon gillnetting between 2014 and 2018 in the Buffalo Harbor area

\begin{tabular}{llllllll}
\hline Year & Sampling dates & No. net sets & Female & Male & Unknown & Grand total & CPUE \\
\hline 2014 & May 15-June 12 & 22 & $2(0)$ & $30(1)$ & $11(0)$ & $43(1)$ & 0.71 \\
2015 & May 18-June 12 & 39 & $2(2)$ & $20(16)$ & $0(0)$ & $22(18)$ & $37(34)$ \\
2016 & May 9-June 1 & 52 & $1(1)$ & $33(30)$ & $3(3)$ & $1(0)$ & $36(4)$ \\
2017 & May 9-June 13 & 32 & $4(4)$ & $31(0)$ & 319 & 0.36 \\
2018 & May 15-June 7 & 24 & $3(2)$ & $31(0)$ & $2(0)$ & $36(2)$ & 0.42 \\
\hline
\end{tabular}

The number of lake sturgeon implanted with acoustic transmitters within each year are presented in parentheses. Morphometric data can be found in Additional file 2: Table S2

estimation capabilities with the Vemco Positioning System (VPS) that allowed for much more precise position estimates of transmitters within the grid (for details on VPS see Espinoza et al. [6]). During the 2016-2018 study period, we placed receivers in the Niagara River to monitor whether lake sturgeon were transitioning between Buffalo Harbor and the river. Further information on the receivers can be found in Additional file 1: Table S1.

\section{Data analysis}

\section{Filtering GLATOS data}

We examined GLATOS data (queried on June 28, 2019) using R scripts for any suspect, or false, detections due to transmitter collisions and other noise [24]. In addition, we calculated an average swimming speed of $109.73 \mathrm{~cm} / \mathrm{s}$, using Peake et al.s [25] average size and body lengths per second:

$$
\begin{aligned}
\log (E)= & 1.40+(2.26 \times 10-2 \times L) \\
& +(5.47 \times 10-2 \times T)-(4.55 \times 10-2 \times V) \\
& -(5.36 \times 10-4 \times T \times V) \\
& +(1.85 \times 10-4 \times L \times V),
\end{aligned}
$$

where water temperature $(T)$ was assumed to be $18{ }^{\circ} \mathrm{C}$ and average length $(L)$ was $148.18 \mathrm{~cm}$. We used the average sustained swimming speed rather than maximum swimming speed because the calculated speed between receiver points does not incorporate receiver detection range. This approach was used by Kessel et al. [26]. Detections were flagged for removal if swimming speeds between detections exceeded $109.73 \mathrm{~cm} / \mathrm{s}$. Given the proximity of receivers to one another, a single transmission could be detected on multiple receivers. These detections were retained if they occurred on receivers within $2.5 \mathrm{~km}$ of one another (given receivers' estimated detection range; Withers unpublished) and fell within the transmitter's nominal delay (100 s). Receiver detection ranges varied from 0.5 to $6 \mathrm{~km}$ (Withers unpublished).

We excluded detections of fish that were tagged in the same calendar year to give fish a year to redistribute naturally. Home ranges and numbers of fish within lake section one would be inflated by newly released sturgeon, especially as all fish were captured during the spawning season. Although tagging effects may not be impacting their behavior, the point of release is autocorrelated with any subsequent movements. By giving the fish a year to redistribute, we eliminate autocorrelation to the best of our ability. For all analyses, we used fish tagged from 2014 to 2017 that were detected during the years 2016-2018.

\section{Large-scale movement}

To examine large-scale spatiotemporal use, we categorized each GLATOS receiver into a lake section given its geographic location (Fig. 2). Lake sections were designed to cover the entire study area, fully contain important array designs like gates, which span the lake width, important bathymetric features, and conformed to the changes in lake-wide configurations throughout the study period. Lake sections were consistent across all analysis years (2016-2018) regardless of detection histories or varying receiver deployments between the years (Fig. 2).

We delineated each year into four seasons; pre-spawn, spawning, summer, and fall based on lake water temperature and receiver deployment and retrieval dates in Buffalo Harbor (Table 2). The pre-spawn season began when the final Buffalo Harbor receiver was deployed in a calendar year, and ended when water temperature in Buffalo Harbor reached $10{ }^{\circ} \mathrm{C}$ (Buffalo Water Treatment Plant at a depth of $9.14 \mathrm{~m}$ by the National Weather Service; https://www.weather.gov/buf/LakeTemp). Since spawning has been reported to occur between 8.8 and $21.0{ }^{\circ} \mathrm{C}$ with peak spawning reported between 11.5 and $16.0{ }^{\circ} \mathrm{C}$ [27], a range of $10.0-18.0^{\circ} \mathrm{C}$ was chosen as a midpoint between observed and peak spawning to delineate our spawning season. Following the spawning season, our summer season ended on the date when the peak water temperature for the year was measured. Our fall season followed our summer season and ended when the first receiver in the Buffalo Harbor array was retrieved in a given year. 

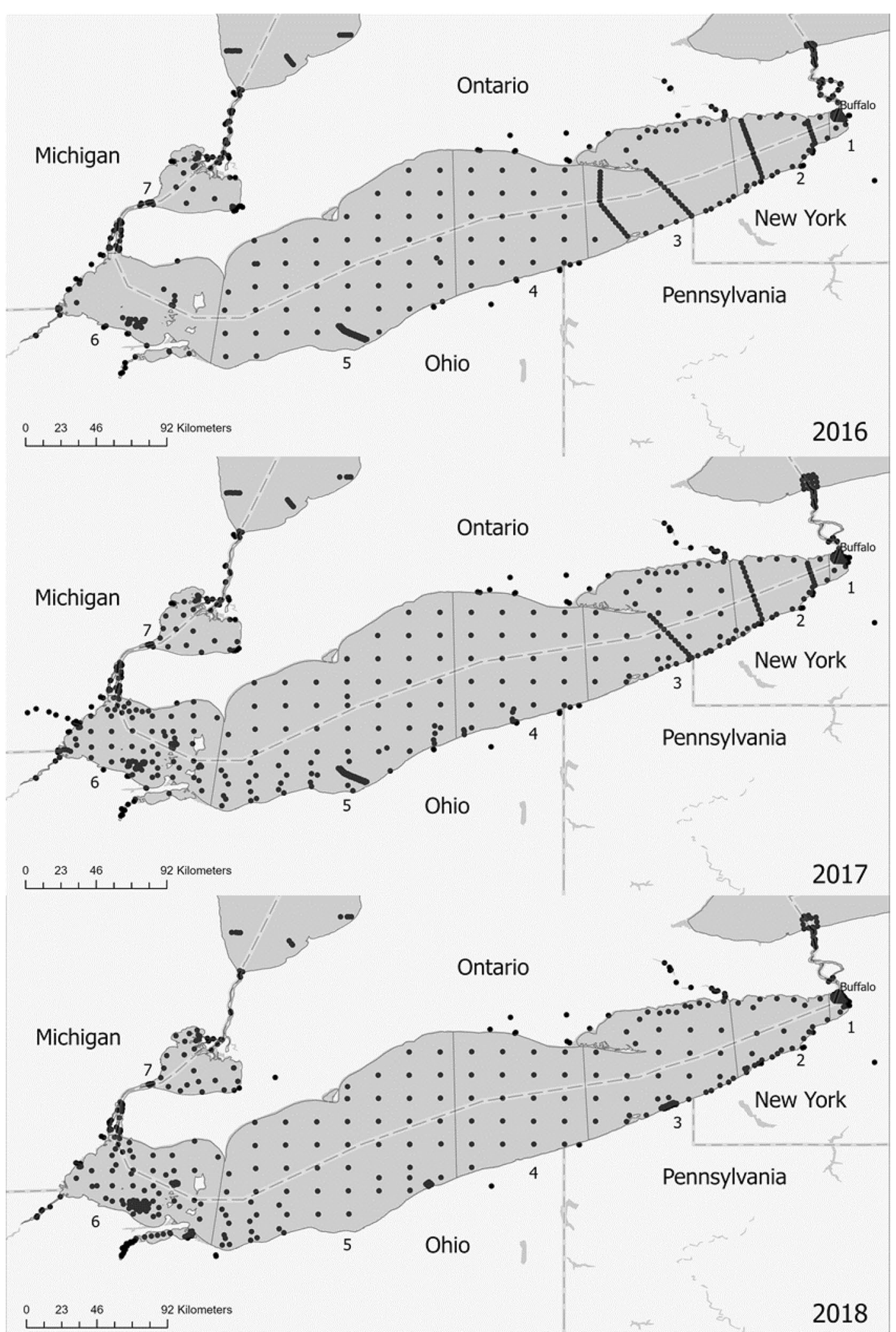

Pennsylvania

Fig. 2 Lake Erie lake sections and deployed GLATOS receivers, 2016-2018. Black dots are GLATOS network receivers placed in Lake Erie and its tributaries. The straight lines are the boundaries of the lake sections and the numbers are the lake sections as described in the text. As time went on, lines of receivers stretching across the lake from US to Canada were gradually replaced with a grid-style array 
Table 2 Beginning and ending dates for seasonal designations used in acoustic telemetry data analysis of lake sturgeon tagged in the Buffalo Harbor area of Lake Erie

\begin{tabular}{llllll}
\hline Year & Pre-spawning & Spawning & Summer & Fall & Total days \\
\hline 2016 & March 30-May 14 & May 15-June 17 & June 18-August 14 & August 15 to September 27 & 181 \\
2017 & March 31-May 14 & May 15-June 10 & June 11-July 25 & July 26-October 16 & 199 \\
2018 & April 27-May 20 & May 21-June 18 & June 19-August 18 & August 19-October 9 & 165 \\
\hline
\end{tabular}

Seasons were based upon water temperatures in recorded by the National Weather Service near the Buffalo water treatment intake at $9.1 \mathrm{~m}$ of depth. Spawning season began when water temperature passed $10^{\circ} \mathrm{C}$, Summer season began when water temperature passed $18^{\circ} \mathrm{C}$, and Fall season began once water temperatures began to decline

To help visualize the spatiotemporal distribution of lake sturgeon in this study, we used detection histories of tagged individuals to categorize them into lake sections, across seasons and years, on a daily time step. If a lake sturgeon was detected in a section on a given day it received a "presence" classification. Lake sturgeon that were detected within multiple lake sections within a given day would receive a "presence" for each section they were detected on within that day. If a lake sturgeon was not detected in any section on a given day, the previous section the lake sturgeon was detected in would be carried forward. If a fish was not detected at the beginning of the year, the first section the fish was detected in would be carried backward. After classifying tagged individuals into sections for each day, we created boxplots of the amount of days each lake sturgeon spent within each lake section for each season and year.

We used a multi-state mark-recapture model to examine the movement rates into and out of the eastern most section of the lake that included Buffalo Harbor (Section-1 vs. all other sections combined; Fig. 2). Multi-state tagging models analyze the tag data in a manner that separates states, which is a more complex and realistic analysis than presence (detection) or absence (non-detection) as the only states. This assumes that the survival of an animal at time $i$ to $i+1$ is not dependent on, in this case, the lake section, which separates survival and movement [28]. Any mortality was assumed to occur prior to any movement in a time period. The detection event was defined as one of four seasons as described in the large-scale analysis section (Table 2). The locations used in the analysis were Section-1, as labeled in Fig. 2, and a second section that is remainder of the lake west of Section-1. The number of fish per year were 19 in 2016, 53 in 2017, and 56 in 2018 and these fish were used for all seasons in those years. Mark-recapture analyses were conducted using the program MARK version 9.0 [29]. The model was used to estimate transition probabilities between lake sections across seasons within a year. States for the model were Section-1 (Buffalo Harbor array area), the rest of the lake, and "0" for no detections in any lake section (i.e., interpolated daily "presence" were excluded from this analysis). Survival was assumed to be constant throughout the lake and initially estimated as 1.0 , as the tag detections suggested little to no mortality of fish during the study period. (Only one of the tagged fish stopped being detected during the study period.)

The multi-state mark-recapture model was intended to provide additional qualitative understanding of the movement of lake sturgeon that are spawning in Buffalo Harbor. Data were limited and resulting model selection was based on those that produced successful runs. There were three models, one for each year analyzed (2016, 2017, and 2018). All were run using a Logit link function with survival assumed to be 1.0 .

\section{Small-scale movement}

To identify the utilization distribution (UD, [30]) of telemetered fish, we analyzed VPS data collected in 2017 and 2018 using a Brownian bridge movement model (BBMM; [31]). Unlike other utilization distribution models that work with discrete location data, the BBMM attempts to account for space used by the animal when location data are unavailable. The BBMM model uses sequential location data and the time between consecutive location points to calculate the occurrence intensity for an animal within a given grid-cell. Small time intervals between location points create high occurrence intensities in cells directly between the two points (a linear path); however, as time between locations increases, the probability an animal moves along a linear path diminishes. Therefore, the BBMM performs best on discrete location data that have relatively short time intervals between locations. We set cell size to $30 \mathrm{~m}^{2}$ and breaks at 5 -h intervals. We calculated BBMMs for each individual fish for each season and year. We then summed seasonal BBMMs across fish and calculated $50 \%$ seasonal home ranges [32].

Though data were collected between 2015 and 2018 in this array, VPS locations collected in 2015 and 2016 were inconsistent spatially and temporally given the relatively sparse array design, particularly 2015 which was not used in the large-scale analyses. Though centers of activities have been used in the past to estimate locations of 
animals when positioning systems are not available [33, 34 , we found errors associated with these estimates were too large to include in our fine-scale analysis (Withers unpublished). Thus, analysis of small-scale movement data was restricted to 2017 and 2018.

\section{Results}

\section{Filtering and interpolation}

Our filtering criteria removed 4,799,889 detections of $12,412,916$ total detections (39\%). The number of days where lake sturgeon positions were interpolated varied by season, year, and individual (Fig. 3). Generally, the proportion of days interpolated constituted less than $25 \%$ of a season. The proportion of days interpolated was relatively higher in the summer and fall of 2018 than other seasons and years. All large-scale movements of lake sturgeon from one lake section to another happened sequentially (i.e., lake sturgeon did not pass through a given lake section without coming from, or moving into, an adjacent lake section).

\section{Large-scale movement}

Our large-scale movement analysis showed that lake sturgeon displayed high site-fidelity to eastern basin of Lake Erie, with greater than $50 \%$ of unique individual detections located in Section-1 during any given season.
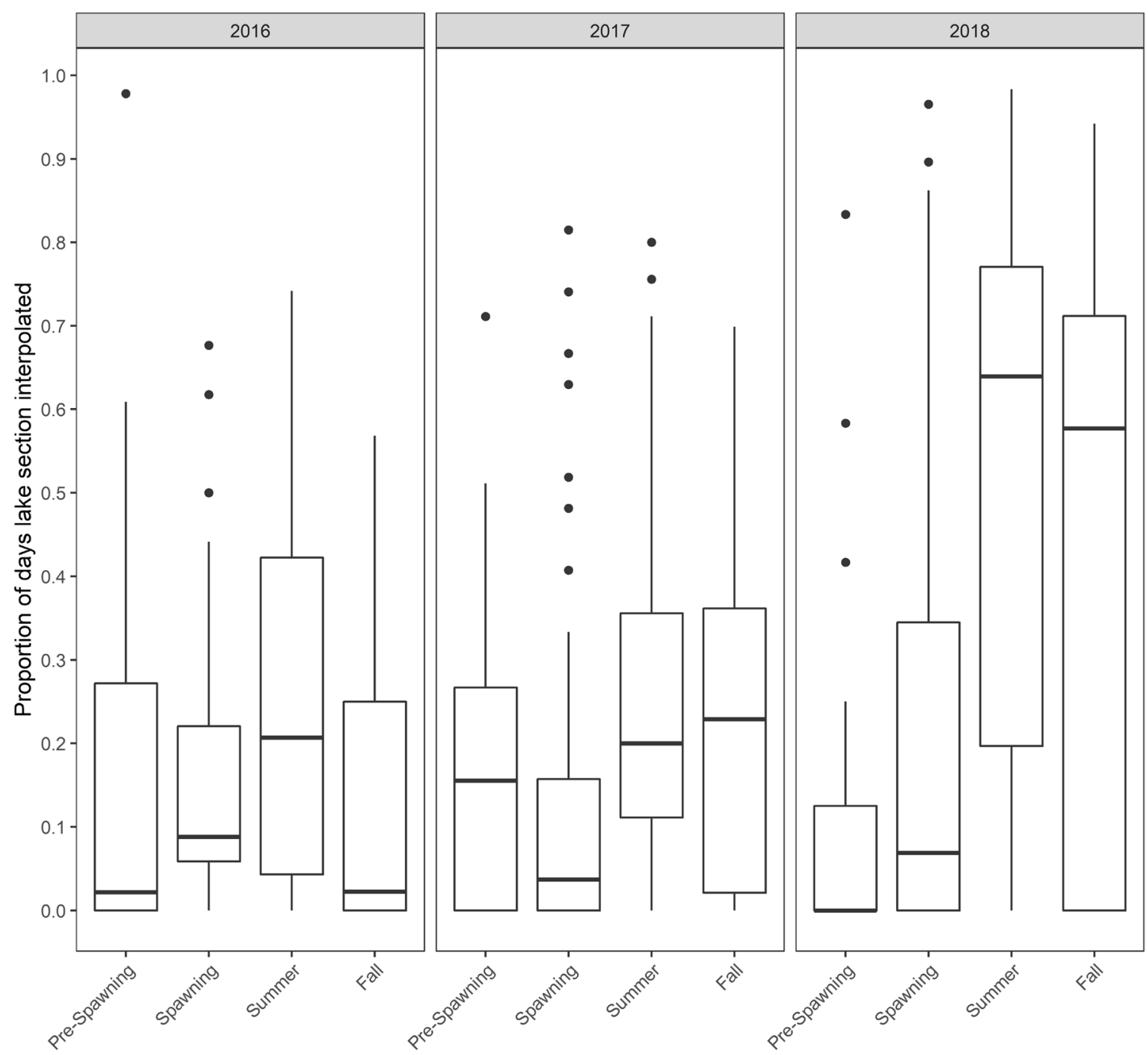

Season

Fig. 3 The proportion of days in a given season and year where acoustically tagged lake sturgeon were not detected. For each of these days, the position of the lake sturgeon was interpolated from the previous detection, except in the case where a lake sturgeon had not been detected at the beginning in the year. In these cases, the position of the lake sturgeon would be interpolated using the subsequent detection 
However, there did appear to be some variation in the distribution of lake sturgeon within the eastern basin depending on season, year, or individual (Table 3; Fig. 4). With the exception of two individuals in 2018, all lake sturgeon remained in the eastern basin of Lake Erie in all seasons and years (Table 3; Fig. 4). In all years, the number of unique individuals detected within a section decreased from Section-1 to Section-7, with nearly all fish being detected in Section-1 in every year and season. During our pre-spawning and spawning seasons, most lake sturgeon spent the majority of their time in Section-1 followed by Section-2 in 2016 and 2017 and followed by Section-3 in 2018. Although the majority of tagged individuals were detected within Section-1, tagged lake sturgeon spent more days in Section-2 in 2016 and 2017 during our summer season. Additionally, a few sturgeon spent much of their time outside of Section-1 in 2018. During the fall, patterns observed during the summer season generally persisted, but fish spent more time in Section-1 in 2016 and more fish were detected in Section-2 in 2018.

The MARK multi-state model results provided further detail to tagged fish movement direction. In 2016, the transition probability of emigrating from Section-1 was $<0.001$ from pre-spawning to spawning season, increased to 0.278 from spawning to summer, and then increased to 0.308 from summer to fall. The 2016 transition probability into Section-1 was $<0.001$ for prespawning to spawning, remained the same for spawning to summer, then increased to 0.333 for summer to fall (Fig. 5). For 2017, the Section-1 transition probability of emigrating from Section-1 was 0.104 from pre-spawning season to spawning, increased to 0.422 from spawning to summer, and then decreased to 0.231 from summer to fall. In 2017, the transition probability into Section-1 was 0.500 for pre-spawning to spawning, decreased to $<0.001$ for spawning to summer, then increased to 0.231 for summer to fall (Fig. 5). The 2018 transition probabilities out of Section-1 were noticeably lower than 2016 and 2017 at $<0.001$ for pre-spawning to spawning, $<0.001$ for spawning to summer, and 0.037 for summer to fall transitions. For the 2018 transitions into Section-1 started much higher than previous years at 0.500 for pre-spawning to spawning, decreased to 0.334 for spawning to summer, and decreased again to 0.000 for summer to fall.

Although the majority of tagged lake sturgeon remained in or near Section-1 during this study, a few individuals exhibited unusually long-distance movements or atypical behavior. In 2018, two tagged fish were detected in the Detroit River/Lake St Clair area in western Lake Erie. Those fish moved to the western part of the lake at different times of the year, one moving during the pre-spawning period and the other detected in the western lake basin late in the year after the post-spawning periods. On the opposite end of the movement spectrum, across all detections and years there were two fish that were detected only within Buffalo Harbor. The other fish that exhibited unusual behavior was tagged in 2016 and detected during the pre-spawning season of 2017, but never detected again. This lake sturgeon was last detected in the eastern basin in the area of the breakwall and Bird Island Reef. It is possible that this fish may have resided or died within the Niagara River, Buffalo River, or another location where it would not have been detected.

Table 3 Individual lake sturgeon detections by lake section, season, and year in Lake Erie (2016-2018)

\begin{tabular}{|c|c|c|c|c|c|c|c|c|c|}
\hline \multirow[t]{2}{*}{ Year } & \multirow[t]{2}{*}{ Tags at large } & \multirow[t]{2}{*}{ Season } & \multicolumn{7}{|c|}{ Lake sections } \\
\hline & & & 1 & 2 & 3 & 4 & 5 & 6 & 7 \\
\hline \multirow[t]{4}{*}{2016} & 19 & Pre-Spawning & $18(90.0 \%)$ & $2(10.0 \%)$ & 0 & 0 & 0 & 0 & 0 \\
\hline & & Spawning & $18(58.1 \%)$ & $13(41.9 \%)$ & 0 & 0 & 0 & 0 & 0 \\
\hline & & Summer & $19(55.9 \%)$ & $15(44.1 \%)$ & 0 & 0 & 0 & 0 & 0 \\
\hline & & Fall & $19(65.5 \%)$ & $10(34.5 \%)$ & 0 & 0 & 0 & 0 & 0 \\
\hline \multirow[t]{4}{*}{2017} & 53 & Pre-Spawning & $51(68.9 \%)$ & $21(28.4 \%)$ & $2(2.7 \%)$ & 0 & 0 & 0 & 0 \\
\hline & & Spawning & $50(58.8 \%)$ & 35 (41.2\%) & 0 & 0 & 0 & 0 & 0 \\
\hline & & Summer & $50(53.2 \%)$ & $43(45.7 \%)$ & $1(1.1 \%)$ & 0 & 0 & 0 & 0 \\
\hline & & Fall & $51(55.4 \%)$ & $40(43.5 \%)$ & $1(1.1 \%)$ & 0 & 0 & 0 & 0 \\
\hline \multirow[t]{4}{*}{2018} & 56 & Pre-Spawning & $50(82.0 \%)$ & $6(9.8 \%)$ & $3(4.9 \%)$ & $1(1.6 \%)$ & $1(1.6 \%)$ & 0 & 0 \\
\hline & & Spawning & $53(76.8 \%)$ & $8(11.6 \%)$ & $4(5.8 \%)$ & $1(1.4 \%)$ & $1(1.4 \%)$ & $1(1.4 \%)$ & $1(1.4 \%)$ \\
\hline & & Summer & $52(96.3 \%)$ & 0 & 0 & 0 & 0 & 1 (1.9\%) & $1(1.9 \%)$ \\
\hline & & Fall & $53(63.9 \%)$ & $27(32.5 \%)$ & $1(1.2 \%)$ & 0 & 0 & $1(1.2 \%)$ & $1(1.2 \%)$ \\
\hline
\end{tabular}

Both numbers and percentage of unique individuals within a lake section are presented. Total number of unique individuals across lake sections may be higher than the number of tagged fish at large as individuals could have been detected in multiple lake sections during a season 


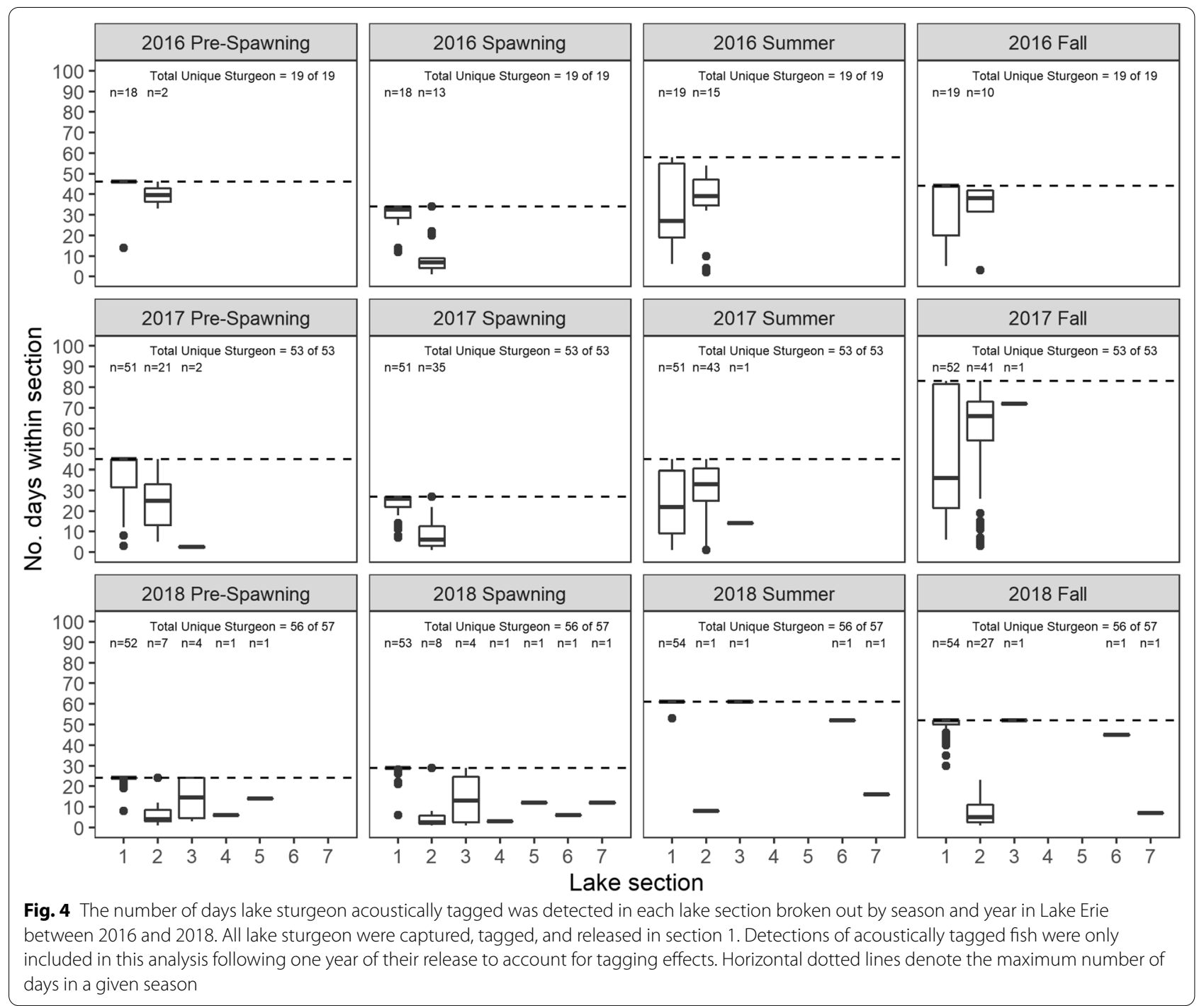

\section{Small-scale movement}

The 2 years that were analyzed showed similar spatial distributions across seasons (Figs. 6 and 7). During the pre-spawning season, lake sturgeon were concentrated along a breakwall and in the area of Bird Island Reef in the eastern and northeastern portions of our array near Buffalo, NY. Additionally, a small group was congregated in the northwestern portion of Buffalo Harbor, just offshore of the Canadian shoreline. During the spawning season, lake sturgeon displayed a similar spatial distribution as observed in the pre-spawning season but tagged individuals spent more time towards the northern portion of the array near the breakwall and Bird Island Reef. Following the spawning season, the fish exhibited greater movement as was evidenced by high UD probability that was spread over a greater area of Buffalo Harbor, forming detectable tracks in Buffalo Harbor. The concentrations along the breakwall and Bird Island Reef were no longer apparent, with concentrations becoming stronger in the northwestern portion of our array off the Canadian shoreline and a new congregation forming at the southern edge of our array, leading to the rest of Lake Erie. The fall seasons showed similar distribution patterns seen during the summer seasons, with movement tracks detected and increased concentrations in the area off the Canadian shoreline.

\section{Discussion}

Overall, our study found that lake sturgeon tagged in Buffalo Harbor have a strong tendency to remain in the eastern basin of Lake Erie. Small-scale home ranges changed by season, with lake sturgeon congregated in the northern and eastern portions of Buffalo Harbor 


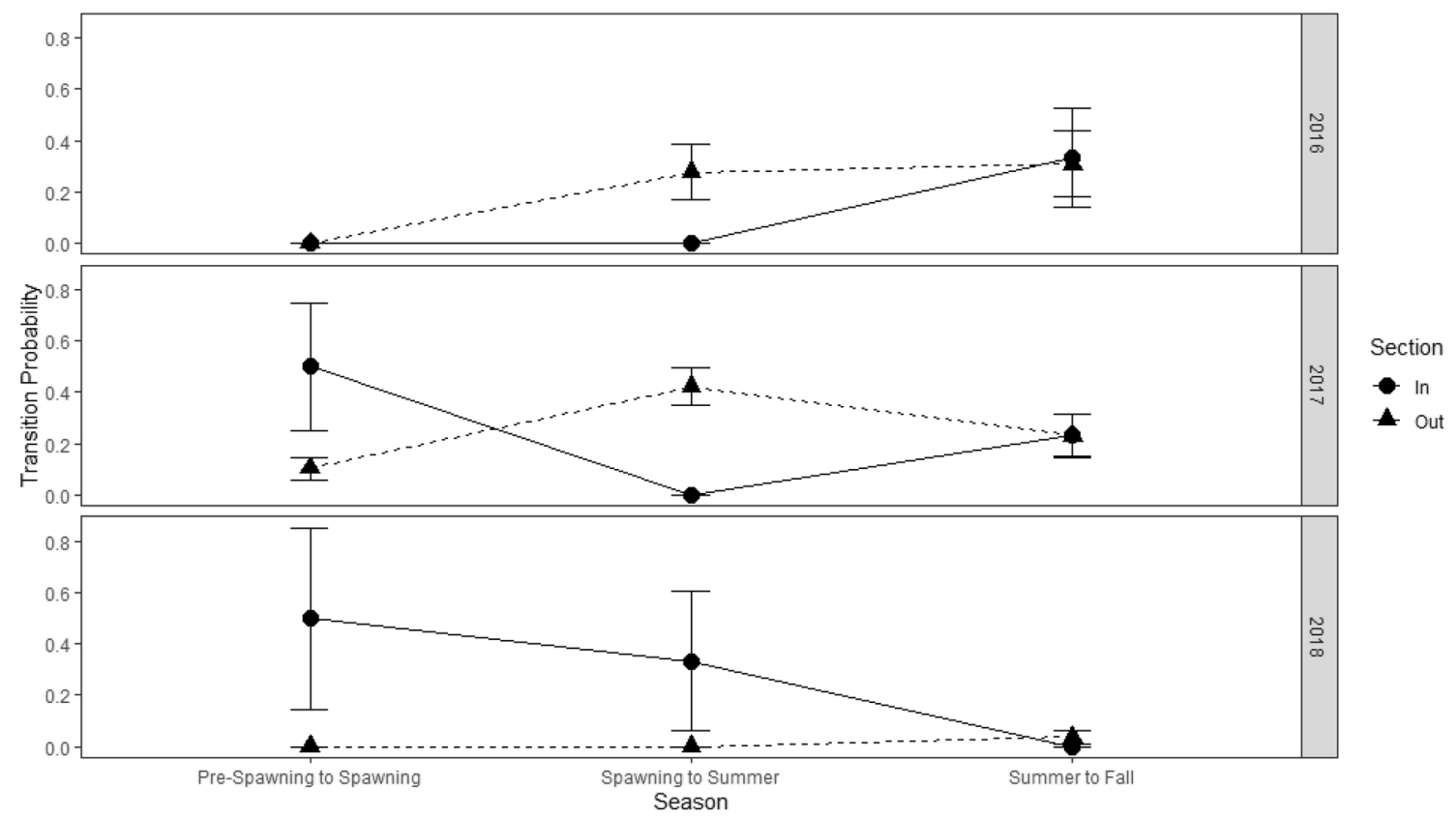

Fig. 5 Transition probabilities of lake sturgeon into and out of Buffalo Harbor area of Lake Erie from 2016 to 2018 as estimated by a multi-state mark-recapture model using program MARK version 9.0 (White and Burnham [29]). The number of fish per year was 19 in 2016, 53 in 2017, and 56 in 2018

during pre-spawning and spawning seasons (Figs. 6 and 7). These areas are known to be important for spawning near the North Gap breakwall and Bird Island Reef (see [16]). Following the spawning season, lake sturgeon headed west, either remaining in Buffalo Harbor and positioning themselves along a deep trough located in the northwest portion (Figs. 6 and 7), or leaving Buffalo Harbor and residing in other areas of Section-1 or Section-2 for the remainder of the year (Table 3; Figs. 4 and 5).

The transition from the eastern side of Buffalo Harbor to the western side of the harbor, or leaving Buffalo Harbor, is likely driven by social, biological, or a combination of social and biological parameters. Rusak and Mosindy [35] concluded that seasonal habitat preferences were likely related to foraging behavior and Boase et al. [44] postulated that sturgeon spawning in the St. Clair River were using habitats based on a combination of invertebrate and sediment composition. Threader et al. 1998 developed a habitat suitability model that used substrate as a surrogate of benthos production. The substrate of the eastern and northeastern side of Buffalo Harbor is mainly composed of patches of large rock rubble and small patches of sand that is very conducive to spawning, whereas the western and southern portion of our array is composed of bedrock and large areas of sand that likely are better foraging grounds. Additionally, the southwestern and western portion of Buffalo Harbor is deeper than much of the eastern side, with depths increasing from northeast to southwest and a trough running along the western portion of the Harbor. This trough, the southwestern portion of Buffalo Harbor, and Section-2 likely provide lake sturgeon with deeper habitat that could act as a thermal refuge or provide feeding opportunities for lake sturgeon during the warmer summer season. Additionally, lake sturgeon may be congregating in the western and southwestern side of our array throughout the fall season as a means staging wherein lake sturgeon prepare to migrate to deeper waters to overwinter to avoid ice scouring. It has been suggested that sturgeon movement out of spawning rivers was related to avoiding adverse conditions like stranding and predator exposure $[36,37]$.

While fish were consistently detected in Buffalo Harbor throughout the study period, no fish were detected in the Niagara River. The river is in close proximity to the known spawning area of Bird Island Reef [16] and could be used by larval or juvenile lake sturgeon that drift downstream post-hatch and remain in the river until sexually mature. Despite never detecting lake sturgeon in the river, recreational divers and anglers have reported lake sturgeon presence within the river. We hypothesize that these may be immature fish and once fish mature, they migrate upstream into the main portion of the lake 


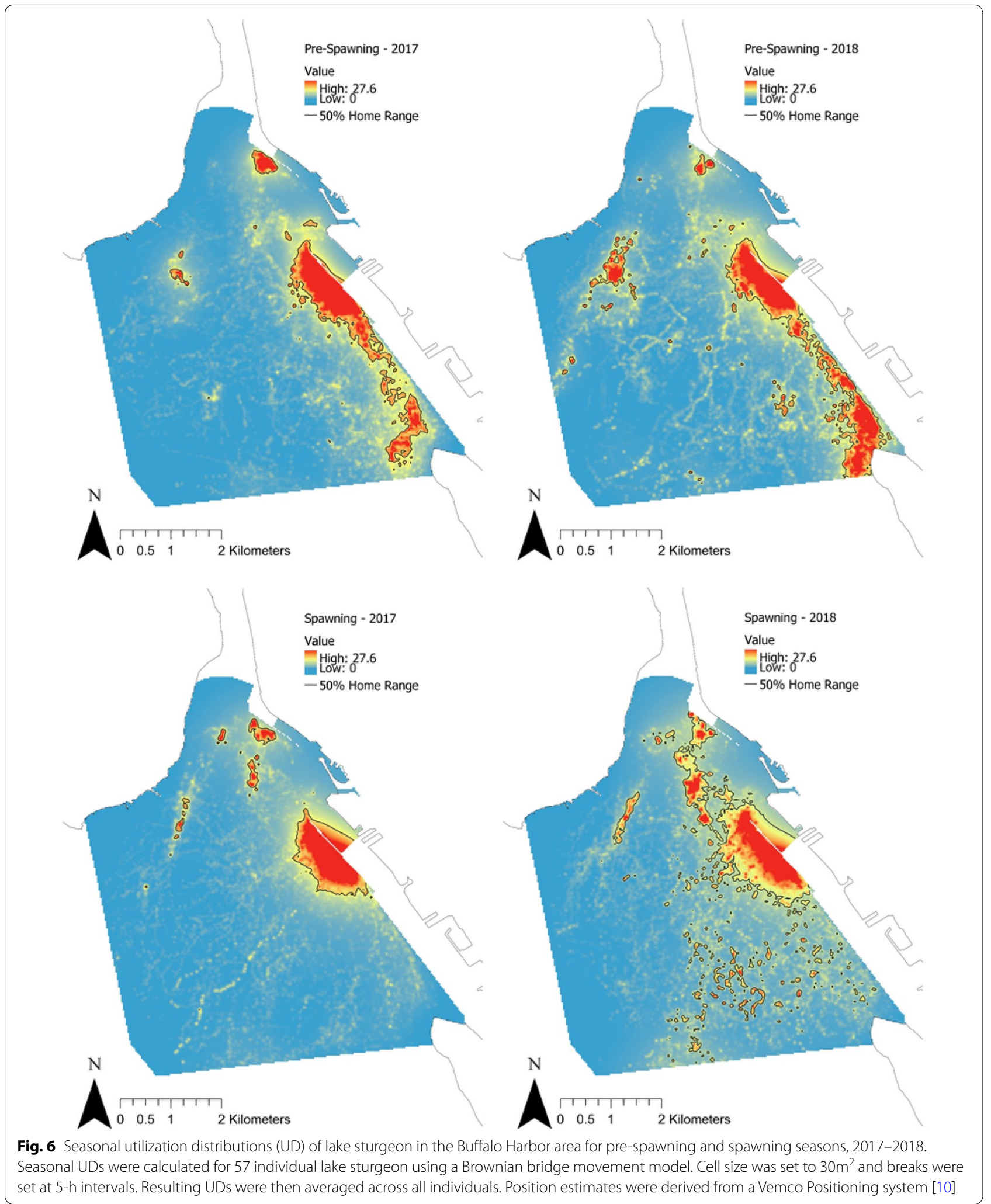




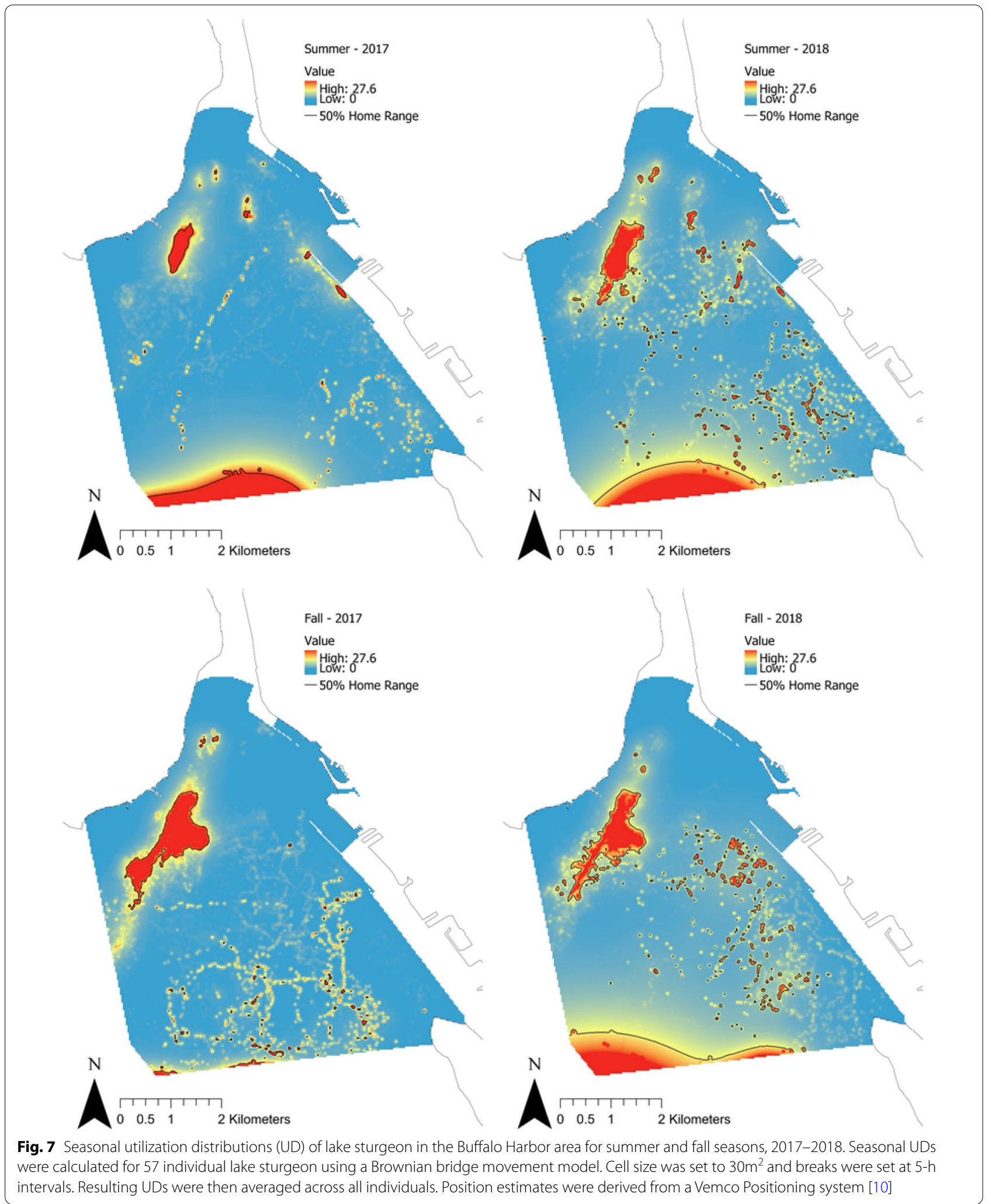


and do not return to the river. Further surveying of lake sturgeon in the area could help understanding the habitat usage and movement patterns for all life stages of this population.

Lake sturgeon are known to migrate great distances, in some cases distances in excess of $200 \mathrm{~km}$ have been observed [35, 36, 38]. However, lake sturgeon are thought to be philopatric $[36,39-43]$ and more recent acoustic telemetry studies have demonstrated lake sturgeon show high site-fidelity; specifically near delta-like areas (St. Clair River [44], Winooski River (C. McKenzie pers. Comm.), lower Niagara River (D. Gorsky, pers. comm.) St. Marys River [45]). These delta-like areas are in proximity to high flow areas suitable for spawning and provide slack water areas where sturgeon can reserve energy. Despite high site-fidelity, our tagged lake sturgeon displayed seasonal small-scale movements and occasionally exhibited large-scale movements, which was similar to results found for lake sturgeon spawning in the St. Clair River where two fish were suspected to have traveled into Lake Huron [44].

While the majority of fish remained in the eastern part of Lake Erie, two fish were detected in western Lake Erie in the area of the Detroit River and Lake St Clair. Previous research found lake sturgeon stocks outside of Lake Superior were genetically similar within the Laurentian Great Lakes [42] while more recent genetic analysis specific to lake sturgeon from Lake Erie found that lake sturgeon from the western lake basin (Detroit River/Lake St Clair) were the same genetic population as those from the eastern basin of the lake (Buffalo Harbor/Niagara River) (M. Bartron, pers. comm.). These are two lines of evidence of mixing between lake sturgeon from the eastern and western ends of Lake Erie. Others have shown lake sturgeon can undergo large migrations related to spawning activities [36]. The potential mixing of populations has implications for management with the potential for mismatches between population structure and spatial management areas. Failing to recognize these mismatches can result in management systems that increase the vulnerability of local subpopulations to depletion [46].

Some aspects of both the Buffalo Harbor and lake-wide receiver deployments limited the possible analyses that could be conducted. Our analyses did not include data between fall and pre-spawning seasons due to limited receiver coverage; all receivers in Buffalo Harbor were removed in the fall and were not deployed again until the following spring. This occurred to prevent receiver damage or loss due to winter ice flows in this relatively shallow area of the lake. Another issue was that the arrangement and density of the lake-wide GLATOS receivers changed from year to year during the study period. The most notable change occurred in 2018 when the spatial distribution of receivers in the eastern basin of Lake Erie (Sections-2 and -3) shifted from a gate design (receivers in relatively tight straight lines stretching across the lake from the US shoreline to the Canada shoreline), to a grid design (Fig. 2). The removal of these gates, particularly in Section-2, likely reduced the probability of detecting lake sturgeon in these sections as demonstrated in Fig. 3. This may explain why we saw a higher proportion of lake sturgeon spending more of their time in Section-2 during 2016 and 2017 but not in 2018. Lake sturgeon could have been present in Sections- 2 and -3 in the same locations year to year, but may not have been detected as frequently, or at all, in 2018 due to array changes and resulting differences in the probability of detection. Such changes over time are inevitable in a system like GLATOS, which comprised multiple study arrays with different research objectives and study periods; however, recent shifts towards establishing a standardized, consistent, grid-like array throughout Lake Erie will provide researchers with a foundation of receivers that will help standardize large-scale, year-to-year analyses.

It is important to note that the vast majority of fish tagged during the study years were male. This was not unexpected given when and where we captured lake sturgeon for tagging, which was during the spawning season and close to an area where spawning has been documented. Lake sturgeon do not spawn annually and males spawn more frequently than females [36, 47-49]. This increases the likelihood that males will be encountered when sampling a spawning area. Because of the skewed sex ratio of the tagged fish, the results are most representative of the movement of male fish.

\section{Conclusions}

Like many other lake sturgeon populations, individuals occupying Buffalo Harbor exhibit strong site-fidelity to the delta-like area where a river and lake intersect but do show some exceptionally large-scale migrations. Additionally, movement and site selection vary by season and likely is being driven by biological cues such as temperature, feeding, and spawning. Buffalo Harbor has been documented as a spawning site for lake sturgeon, but this study found that many lake sturgeon continued to reside within, or relatively close to, Buffalo Harbor throughout the year demonstrating the importance of this area beyond the spawning season. Lake sturgeon also demonstrated large-scale movements as tagged sturgeon traveled from the eastern end of Lake Erie to the western end and into Lake St. Clair (>450 km), occupying and traversing multiple lake sections across seasons. This study demonstrates the value of the GLATOS network and the data derived from 
the GLATOS network in providing managers with an understanding of the range, ability to migrate, disperse, and stray rate of migratory fish populations while also identifying areas that may require greater data collection for small-scale analyses. This study also demonstrates that the implementation of small-scale analyses provides managers with information pertaining to critical habitat within highly utilized areas. This information provides evidence to managers for the need to develop bi-national and multijurisdictional management strategies.

\section{Supplementary Information}

The online version contains supplementary material available at https://doi. org/10.1186/s40317-021-00263-X.

Additional file 1: Table S1. Description of Vemco receivers that were deployed in the Buffalo Harbor area from 2015 to 2018. Includes receiver ID, Vemco receiver type, frequency, and years deployed.

Additional file 2: Table S2. Morphometric data on all lake sturgeon sampled from 2015 to 2018. Weight is measured in kilograms. Total length, fork length, and girth are measured in centimeters. Unavailable or not applicable data are denoted with' '-'

\section{Acknowledgements}

We thank the New York Department of Environmental Conservation Lake Erie Fishery Unit and Region 9 for assistance with capturing and processing lake sturgeon. Thanks goes to GLATOS and participating members of GLATOS. Thanks to Nicholas Markley and the many other staff at the US Fish and Wildlife Service Northeast Fishery Center and Lower Great Lakes Fish and Wildlife Conservation Office for their assistance with sampling and equipment maintenance. We thank Mark Clapsadl and staff at the Buffalo State College Great Lakes Science Center for equipment storage and providing facility space. Thank you Chief Timothy Rafter and the Aids to Navigation unit of the Buffalo, NY United States Coast Guard for equipment storage and providing facility space. The findings and conclusions in this article are those of the authors and do not necessarily represent the views of the U.S. Fish and Wildlife Service.

\section{Authors' contributions}

$J L W, J S$ conceived the ideas and designed the study; JLW, LD, RN, and JS collected the data; JLW, HTH, and SA analyzed the data, JLW and HTH led the writing of the manuscript; all authors contributed critically to the drafts. All authors read and approved the final manuscript.

\section{Funding}

Funding was provided by the Great Lakes Restoration Initiative.

\section{Availability of data and materials}

The datasets and code produced during our study are available from the corresponding author by request.

\section{Declarations}

\section{Ethics approval and consent to participate}

All applicable international, national, and institutional guidelines for care and use of animals were followed. In particular, fish were caught and handled following recommendations contained in the American Fisheries Society's guidelines for the Use of Fishes in Research authored by a joint committee of the American Fisheries Society, the American Institute of Fishery Research Biologists, and the American Society of Ichthyologists and Herpetologists (located at https://fisheries.org/policy-media/science-guidelines/guide lines-for-the-use-of-fishes-in-research/). Of particular relevance are sectsions 5.3 (Live Capture Techniques and Equipment), 5.4 (Field Restraint of Fishes:
Sedatives), and 6.1-6.3 (Marking and Tagging General Principles, External Tags and Marks, Internal Tags and Marks, and Biotelemetry).

\section{Consent for publication}

Not applicable.

\section{Competing interests}

The authors declare no competing interests.

\section{Author details}

${ }^{1}$ Northeast Fishery Center, U.S. Fish \& Wildlife Service, P.O. Box 75, Lamar, PA 16848, USA. ${ }^{2}$ U.S. Army Corps of Engineers, Portland District, 333 SW 1st Ave, Portland, OR 97204, USA. ${ }^{3}$ Wyoming Geographic Information Science Center, University of Wyoming, Dept. 4008, 1000 E. University Ave, Laramie, WY 82071, USA.

Received: 29 March 2021 Accepted: 8 September 2021

Published online: 18 September 2021

\section{References}

1. Meyer CG, Papastamatiou YP, Holland KN. A multiple instrument approach to quantifying the movement patterns and habitat use of tiger (Galeocerdo cuvier) and Galapagos sharks (Carcharhinus galapagensis) at French Frigate Shoals. Hawaii Mar Biol. 2010;157:1857-68.

2. Dean MJ, Hoffman WS, Zemeckis DR, Armstrong MP. Fine-scale diel and gender-based patterns in behaviour of Atlantic cod (Gadus morhua) on a spawning ground in the Western Gulf of Maine. ICES J Mar Sci. 2014;71:1474-89.

3. Hayden TA, Holbrook CM, Fielder DG, Vandergoot CS, Bergstedt RA, Dettmers JM, Krueger CC, Cooke SJ. Acoustic telemetry reveals largescale migration patterns of Walleye in Lake Huron. PLoS ONE. 2014;9(12): e114833. https://doi.org/10.1371/journal.pone.0114833.

4. Hussey NE, Kessel ST, Aarestrup K, Cooke SJ, Cowley PD, Fisk AT, Harcourt RG, Holland KN, Iverson SJ, Kocik JF, Mills Flemming JE, Whoriskey FG. Aquatic animal telemetry: a panoramic window into the underwater world. Sci. 2015;348:1255642.

5. Hockersmith EE, Beeman JW. A history of telemetry in fishery research. In: Telemetry techniques: a user guide for fisheries research, p. 542;2012.

6. Espinoza M, Farrugia TJ, Webber DM, Smith F, Lowe CG. Testing a new acoustic telemetry technique to quantify long-term, fine-scale movements of aquatic animals. Fish Res. 2011;108:364-71.

7. Harkness WJK, Dymond JR. The Lake Sturgeon: the history of its fishery and problems of conservation. Ontario Department of Lands and Forests, Fisheries and Wildlife Branch, Toronto; 1961.

8. Scott WB, Crossman EJ. Freshwater fishes of Canada. Bull Fish Resour Board Can. 1973;184:1-996.

9. Auer NA. Lake sturgeon: a unique and imperiled species in the Great Lakes. In: Taylor WW, Ferreri CO, editors. Great lakes fisheries policy and management: a binational perspective. East Lansing: Michigan State University Press; 1999. p. 551.

10. Baldwin NS, Saafeld RW, Ross MA, Buettner HJ. Commercial fish production in the Great Lakes 1867-1977. In Gr. Lakes Fish. Comm. Tech. Rep. 3. 1979;p.6, 30, 31, 70, 84-85, 124-125, 158-159.

11. Pikitch EK, Doukakis P, Lauck L, Chakrabarty P, Erickson DL. Status, trends and management of sturgeon and paddlefish fisheries. Fish Fish. 2005;6:233-65.

12. COSEWIC assessment and update status report on the lake sturgeon Acipenser fulvescens in Canada. Committee on the Status of Endangered Wildlife in Canada, Ottawa (xi + 107 pp.). http//:www.sararegistry.gc.ca/ status/status_e.cfm

13. Haxton T, Whelan G, Bruch R. Historic biomass and sustainable harvest of Great Lakes lake sturgeon (Acipenser fulvescens Rafinesque, 1817). J Appl Ichthyol. 2014;30:1371-8.

14. Sweka JA, Neuenhoff R, Withers J, Davis L. Application of a depletionbased stock reduction analysis (DB-SRA) to lake sturgeon in Lake Erie. J Great Lakes Res. 2018;44:311-8.

15. Peterson DL, Vescei P, Jennings CA. Ecology and biology of the lake sturgeon: a synthesis of current knowledge of a threatened North American Acipenseridae. Rev Fish Biol Fish. 2007;17:59-76. 
16. Neuenhoff RD, Withers JL, Davis LA, Markley ND, Dowell S, Bartron ML, Gorsky D, Sweka JA. Discovery of an undocumented Lake Sturgeon spawning site in the headwaters of the Niagara River. J Fish Wildl Manag. 2018;9:266-73.

17. Withers JL, Gorsky D, Biesinger Z, Einhouse D, Clancy M, Davis L, Karboski C, Legard C, Bruestle E, Markley N, Roth R, Zimar R, Sweka JA. Age and growth of Niagara River Lake Sturgeon. J Fish Wildl Manag. 2020;11:634-43.

18. Withers JL, Einhouse D, Clancy M, Davis L, Neuenhoff R, Sweka J. Integrating acoustic telemetry into a mark-recapture model to improve catchability parameters and abundance estimates of lake Sturgeon in Easter Lake Erie. N Am J Fish Manag. 2019;39:913-20.

19. NOAA - Great Lakes Environmental Research Laboratory. About Our Great Lakes: Lake by Lake Profiles [Internet]. Ann Arbor, MI: NOAA - Great Lakes Environmental Research Laboratory; 2012. https://www.glerl.noaa.gov/ education/ourlakes/lakes.html. Accessed 13 Aug 2021.

20. Environmental Protection Agency. Lake Erie [Internet]. [place unknown]: Environmental Protection Agency; 2020. https://www.epa.gov/great lakes/lake-erie. Accessed 13 Aug 2021.

21. Kayle KA, Murray C. Lake Erie's central basin. In: The state of Lake Erie in 2009. 2017. http://www.glfc.org/pubs/SpecialPubs/Sp17_01.pdf. Accessed 19 Mar 2020.

22. Chiotti JA, Boase JC, Hondorp DW, Briggs AS. Assigning sex and reproductive stage to adult lake sturgeon using ultrasonography and common morphological measurements. N Am J Fish Manag. 2016;36:21-9.

23. Rossiter A, Noakes DLG, Beamish EWH. Validation of age estimation for the lake sturgeon. Trans Am Fish Soc. 1995;124:777-81.

24. Simpfendorfer CA, Huveneers C, Steckenreuter A, Tattersall K, Hoenner X, Harcourt R, Heupel MR. Ghosts in the data: false detections in VEMCO pulse position modulation acoustic telemetry monitoring equipment. Anim Biotelemetry. 2015;3:55.

25. Peake SJ, Beamish FWH, McKinley RS, Scruton DA, Katopodis C. Relating swimming performance of lake sturgeon, Acipenser fulvescens, to fishway design. Can J Fish Sci. 1997;54(6):1361-6.

26. Kessel ST, Hondorp DW, Holbrook CM, Boase JC, Chiotti JA, Thomas MV, Wills TC, Roseman EF, Drouin R, Krueger CC. Divergent migrations within Lake Sturgeon (Acipenser fulvescens) populations: multiple distinct patterns exist across an unrestricted corridor. J Anim Ecol. 2018;2018(87):259-73

27. Bruch RM, Binkowski FP. Spawning behaviour of lake sturgeon (Acipenser fulvescens). J Appl Ichthyol. 2002;18:570-9.

28. Joe M, Pollock KH. Separation of survival and movement rates in multi-state tag-return and capture-recapture models. J Appl Stat. 2002;29:373-84.

29. White GC, Bunham KP. Program MARK: Survival estimation from populations of marked animals. Bird Study. 1999;46(Supplement):120-38.

30. Van Winkle W. Comparison of several probabilistic home-range models. J Wildl Manag. 1975;39:118-23.

31. Horne JS, Garton EO, Krone SM, Lewis JS. Analyzing animal movements using Brownian bridges. Ecol. 2007;88:2354-63.

32. Worton BJ. Kernel methods for estimating the utilization distribution in Home-Range studies. Ecol. 1989;70:164-8.

33. Simpfendorfer CA, Heupel MR, Hueter RE. Estimation of short-term centers of activity from an array of omnidirectional hydrophones and its use in studying animal movements. Can J Fish Aquat Sci. 2002;59:23-32.
34. Hedger RD, Martin F, Dodson JJ, Hatin D, Caron F, Whoriskey FG. The optimized interpolation of fish positions and speeds in an array of fixed acoustic receivers. ICES J Mar Sci. 2008:65:1248-59.

35. Rusak JA, Mosindy T. Seasonal movements of Lake Sturgeon in lake of the woods and the rainy river. Ontario Can J Zool. 1997;75:383-95.

36. Auer N. Population characteristics and movement of Lake Sturgeon in the sturgeon river and Lake Superior. J Great Lakes Res. 1999;25:282-93.

37. Thayler D, Rupert JLW, Watkinson D, Clayton T, Poesch MS. Identifying temporal bottlenecks for the conservation of large-bodied fishes: Lake Sturgeon (Acipenser fulvescencs) show highly restricted movement and habitat use over-winter. Glob Ecol Conserv. 2018;10:194-205.

38. Kempinger JJ. Spawning and early life history of lake sturgeon in the Lake Winnebago system. In: Hoyt RD, editor. 11th annual larval fish conference, American Fisheries Society, Symposium 5; 1987; Houghton, MI. Bethesda, MD: American Fisheries Society; 1988, p. 110-122

39. Fortin R, Mongeau JR, Desjardins G, Dumont P. Movements and biological statistics of lake sturgeon (Acipenser fulvescens) from the St. Lawrence and Ottawa River system, Quebec. Can J Zool. 1993;71:638-50.

40. Haxton T. Movement of lake sturgeon, Acipenser fulvescens, in a natural reaches of the Ottawa River. Can Field-Nat. 2003;117:541-5.

41. DeHaan PW, Libants SV, Elliott RF, Scribner KT. Genetic population structure of remnant lake sturgeon populations in the upper Great Lakes basin. Trans Am Fish Soc. 2006;135:1478-92.

42. Welsh A, Hill TD, Quinlan H, Robinson C, May B. Genetic assessment of Lake Sturgeon population structure in the Laurentian Great Lakes. N Am J Fish Manag. 2008:28:572-91.

43. Homola JJ, Scribner KT, Baker EA, Auer NA. Genetic assessment of straying rates of wild and hatchery reared lake sturgeon (Acipenser fulvescens) in Lake Superior tributaries. J Great Lakes Res. 2010;36:789-802.

44. Boase JC, Diana JS, Thomas MV, Chiotti JA. Movements and distribution of adult Lake Sturgeon from their spawning site in the St. Clair River, Michigan. J App Ichthyol. 2011;27:58-65.

45. Gerig B, Moerke A, Greil R, Koproski S. Movement patterns and habitat characteristics of Lake Sturgeon (Acipenser fulvescens) in the St. Marys River, Michigan, 2007-2008. J Great Lakes Res. 2011;37:54-60.

46. Ying Y, Chen Y, Lin L, Gao T. Risks of ignoring fish population spatial structure in fisheries management. Can J Fish Aquat Sci. 2011;68:2101-20.

47. Roussow G. Some considerations concerning sturgeon spawning periodicity. J Fish Res Board Can. 1957;14:553-72.

48. Magnin E. Recherches sur les cycles de reproduction des sturgeons Acipenser fulvescens Rafinesque. Annales de la Station Centrale d'Hydrobiologie Appliquee. 1966;9:8-242.

49. Lyons J, Kempinger JJ. Movements of adult lake sturgeon in the Lake Winnebago system. Madison: Wisconsin Department of Natural Resources; 1992. p. 17

\section{Publisher's Note}

Springer Nature remains neutral with regard to jurisdictional claims in published maps and institutional affiliations.

Ready to submit your research? Choose BMC and benefit from:

- fast, convenient online submission

- thorough peer review by experienced researchers in your field

- rapid publication on acceptance

- support for research data, including large and complex data types

- gold Open Access which fosters wider collaboration and increased citations

- maximum visibility for your research: over 100M website views per year

At BMC, research is always in progress.

Learn more biomedcentral.com/submissions 